\title{
Molecular detection of Trypanosoma evansi (Kinetoplastida: Trypanosomatidae) in procyonids (Carnivora: Procyonidae) in Eastern Amazon, Brazil
}

\author{
Deteç̧ão molecular de Trypanosoma evansi (Kinetoplastida: Trypanosomatidae) \\ em procionídeos (Carnivora: Procyonidae) na Amazônia Oriental, Brasil
}

\author{
Paulo Cesar Magalhães-Matos ${ }^{I}$ Rafaelle Cunha-Santos ${ }^{I}$ Paulo Geovani Silva Sousa ${ }^{I}$ \\ Francisco Dantas Sampaio-Júnior ${ }^{I}$ Flávia de Nazaré Leite Barros ${ }^{I}$ Fábio Rodrigo Paixão Mourão ${ }^{I I}$ \\ Wanessa Batista Lima Oliveira ${ }^{\mathrm{III}}$ Áurea Martins Gabriel ${ }^{\mathrm{IV}}$ Silvia Gonzalez Monteiro $^{\mathrm{V}}$ \\ Gustavo Góes-Cavalcante ${ }^{I}$ Alessandra Scofield ${ }^{I^{*}}$
}

ABSTRACT

The present study aimed to diagnose the natural infection of captive and free-living procyonids with Trypanosoma evansi in the states of Amapá and Pará, Brazil. From February 2012 to August 2013, whole blood samples and blood smears were obtained from 45 free-living procyonids and from nine procyonids kept in captivity in wild life refuges and zoobotanical parks in the states of Amapá and Pará. Whole blood samples were collected and kept at $-20^{\circ} \mathrm{C}$ for the detection of T. evansi DNA by PCR using the RoTat 1.2 forward and RoTat 1.2 reverse primers. In addition, the blood smears were processed and examined for the presence of trypomastigote forms of T. evansi. T. evansi DNA was detected in $18.52 \%$ (10/54) of the procyonids, namely, in captive crabeating raccoons and captive and free-living coatis in Pará State. No trypomastigote forms were observed in the blood smears. DNA from $\boldsymbol{T}$. evansi was detected in $\boldsymbol{P}$. cancrivorus and $\boldsymbol{N}$. nasua in Pará State, being this the first such report in $\boldsymbol{P}$. cancrivorus.

Key words: Trypanosoma evansi, PCR, Procyonidae, Eastern Amazon.

\section{RESUMO}

$O$ objetivo do presente trabalho foi realizar o diagnóstico da infecção natural por Trypanosoma evansi em procionídeos de vida livre e de cativeiro dos estados do Amapá e Pará, Brasil. Durante o período de fevereiro de 2012 a agosto de 2013, amostras de sangue total e esfregaços sanguíneos foram obtidos de 45 procionídeos de vida livre e de nove mantidos em cativeiro em mantenedores e Parques Zoobotânicos dos estados do Amapá e Pará. As amostras de sangue total foram coletadas e mantidas a $-20^{\circ} \mathrm{C}$ para pesquisa de DNA de T. evansi pela PCR utilizando-se os iniciadores RoTat 1.2 forward e RoTat 1.2 reverse. Os esfregaços sanguíneos também foram processados e examinados para a pesquisa de formas tripomastigotas do agente. DNA de T. evansi foi detectado em 18,52\% (10/54) dos procionídeos, ocorrendo em mãos-peladas de cativeiro e quatis de vida livre e de cativeiro no estado do Pará. Não foram observadas formas tripomastigotas nos esfregaços sanguíneos. DNA de $\boldsymbol{T}$. evansi foi detectado em P. cancrivorus e $N$. nasua no estado do Pará, sendo este o primeiro relato em $\boldsymbol{P}$. cancrivorus.

Palavras-chave: Trypanosoma evansi, PCR, Procyonidae, Amazônia Oriental.

\section{INTRODUCTION}

Procyonids (Carnivora: Procyonidae) are small arboreal mammals only found in the Americas, from Canada to Argentina. Species found in Brazil are widely distributed in the country's territory, and the main representatives are the coati (Nasua nasua Linnaeus, 1766), crab-eating raccoon (Procyon cancrivorus Cuvier, 1798), and kinkajou (Potos flavus Schreber, 1774) (EISENBERG \& REDFORD, 1999). Procyonids from the local fauna may be infected with trypanosomatids species of zoonotic importance, including Trypanosoma cruzi (HERRERA et al.,

ILaboratório de Parasitologia Animal, Instituto de Medicina Veterinária, Universidade Federal do Pará (UFPA), Campus Castanhal, BR 316, Km 61, 68740-080, Castanhal, PA, Brasil. E-mail: ascofield@ufpa.br. *Corresponding author.

IISecretaria Municipal de Saúde do Município de Macapá, Coordenadoria de Vigilância Ambiental, Departamento de Zoonoses, Macapá, AM, Brasil.

IIIIndependent biologist, Ananindeua, PA, Brasil.

${ }^{\mathrm{IV}}$ Faculdade de Engenharia Sanitária e Ambiental, Instituto de Tecnologia, Universidade Federal do Pará (UFPA), Belém, PA, Brasil.

vepartamento de Microbiologia e Parasitologia (MIP), Centro de Ciências da Saúde (CCS), Universidade Federal de Santa Maria (UFSM), Santa Maria, RS, Brasil. 
2008) and Leishmania spp. (LAINSON et al., 2010), and may host Trypanosoma evansi (HERRERA et al., 2004).

T. evansi is the causative agent of a disease locally known as "mal das cadeiras", which predominantly affects horses and causes great economic losses in horse breeding (SEIDL et al., 1998). This agent has no known biological vector in the Americas; however, it is mechanically transmitted through the bite of hematophagous insects (BOEHRINGER \& PROSEN, 1961). In some regions of Brazil, as the Pantanal in Mato Grosso do Sul, the role of procyonids in maintaining $T$. evansi in wild habitats has been demonstrated, and these animals are among the main reservoirs of $\boldsymbol{T}$. evansi in these areas (HERRERA et al., 2011).

Elucidating the rate of procyonid infection by $\boldsymbol{T}$. evansi in a particular region may support conservation of the host species and a better assessment of the dynamics of pathogen transmission between wild and domestic animals (JORGE et al., 2010). In the Amazon region, information on procyonid infection rates is scarce. Therefore, the present study aimed to diagnose the natural infection by $\boldsymbol{T}$ evansi in captive and free-living procyonids in the Eastern Amazon region by blood smear analysis and polymerase chain reaction (PCR).

\section{MATERIALS AND METHODS}

Authorization for research

The biological sample collection and search for parasites in procyonids were authorized by the System for Authorization and Information on Biodiversity from the Chico Mendes Institute for Biodiversity (SISBIO/ICMBIO, protocol 30710-1).

Animals and study area

Biologic samples were obtained by convenience from free-living procyonids and animals kept in captivity in wildlife refuges and zoobotanical parks in the states of Amapá and Pará (Figure 1).

The procyonids were identified according to the characteristics described in the Neotropical Rainforest Mammals field guide (EMMONS \& FEER, 1997) and were classified according to the type of habitat into group A (captive animals) and group B (free-living animals). All the specimens

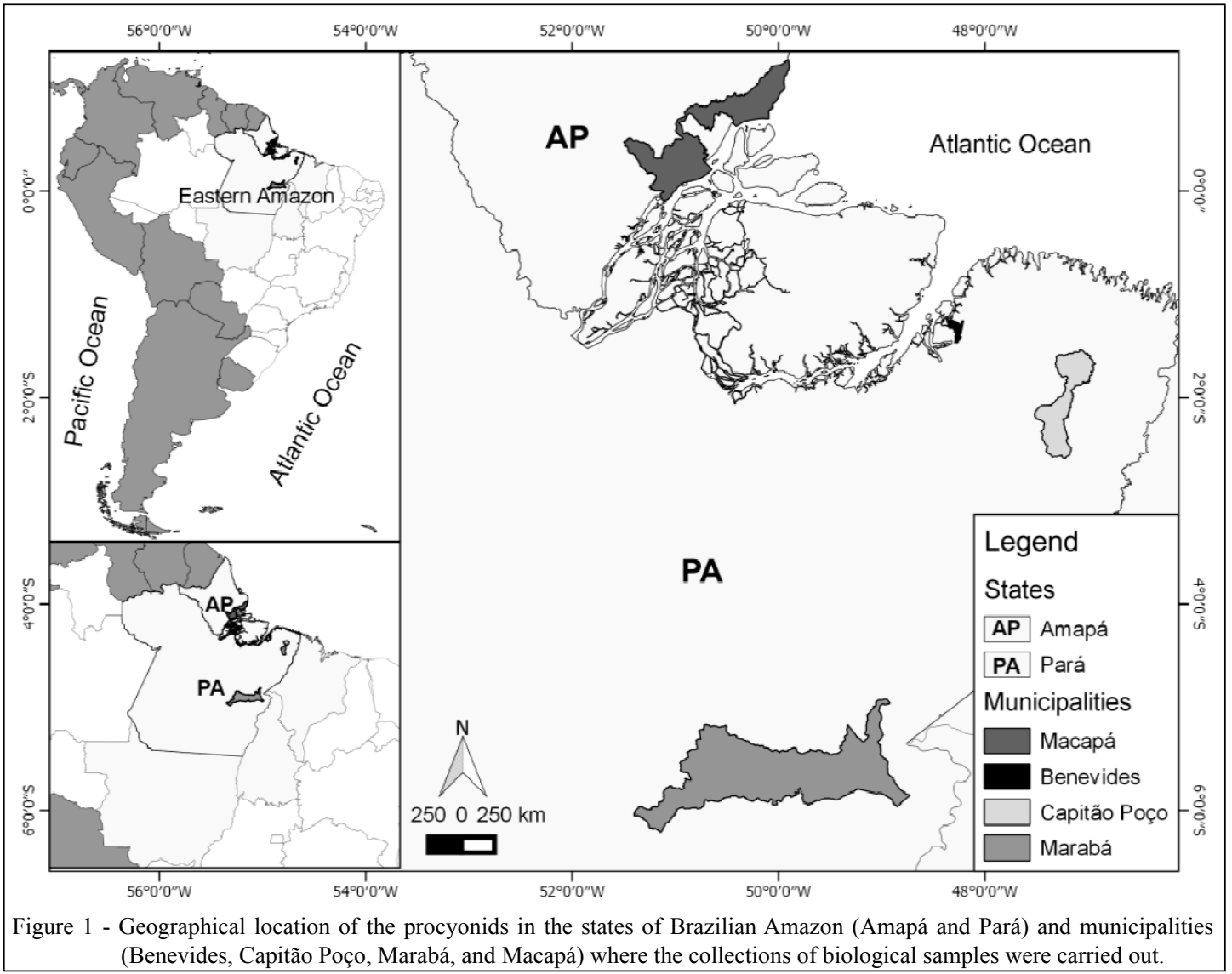

Ciência Rural, v.46, n.4, abr, 2016. 
were identified, sexed, and physically examined, and data on the place of origin, habitat, and nutritional management during captivity were documented on individual forms. The changes observed during anamnesis were also recorded.

Collection and processing of biological samples

From February 2012 to August 2013, biological samples were collected from procyonids (male, female) of varying ages. Animals maintained in captivity were captured and physically restrained using a hand net. Free-living animals were captured with Tomahawk live traps distributed throughout the wildlife refuges and parks. The subjects were physically restrained with the aid of dip nets and anesthetized with tiletamine hydrochloride and zolazepam chloridate (Zoletil 50 ${ }^{\circledR}$, Virbac do Brasil Indústria e Comércio Ltda.), intramuscularly (5-7mg/kg).

Heart and respiratory rates, body temperature, and the oral mucosal color were monitored during the procedures. All the animals were physically inspected, and the mucous membrane color, coat appearance, presence of skin lesions, and body weight were determined. After these procedures, the animals were still monitored until they recovered alertness, then returning to their sites of origin.

Whole blood samples were collected by puncture of the cephalic, femoral, or jugular veins, and an average of $2.0 \mathrm{~mL}$ of blood was collected from each animal. Blood samples were stored in tubes containing EDTA (ethylenediaminetetraacetic acid) and frozen at $-20^{\circ} \mathrm{C}$ for subsequent molecular analysis.

Blood smears were also prepared using capillary blood from the ear, which was collected using sterile hypodermic needles. The smears were airdried, fixed in absolute methanol for three minutes, and stained with $10 \%$ Giemsa $\left(\right.$ Merck $\left.^{\circledR}\right)$ for 40 minutes. Slides were analyzed under an optical microscope (Leica DM-2500) at magnifications of 40X and 100X in order to obtain a morphological characterization of the trypomastigote forms of T. evansi.

DNA was extracted from the blood samples of the procyonids using the Axy Prep Blood Genomic DNA Miniprep kit (Axygen Biosciences ${ }^{\circledR}$ ), following the manufacturer's instructions. To obtain a PCR positive control, DNA was extracted from the blood of a mouse x experimentally infected with $\boldsymbol{T}$. evansi isolate LPV-2005 (COLPO et al., 2005). For the negative control, DNA was extracted from the blood of a PCR-negative $N$. nasua pup that originated from an area non-endemic for T. evansi.

For the detection of T. evansi DNA, PCR was performed using the primers RoTat 1.2 forward
(5'-GCGGGGTGTTTAAAGCAATA-3') and RoTat 1.2 reverse (5'-ATTAGTGCTGCGTGTGTTCG-3'), which amplify a 205-bp fragment of the RoTat 1.2 VSG gene, as described by CLAES et al., (2004). These primers were also used for a virtual analysis with the BLAST-Primer program, available from the National Center for Biotechnology Information (NCBI) website.

To test the specificity of these primers, DNA from $\boldsymbol{T}$. cruzi, Trypanosoma vivax, Leishmania amazonensis, Leishmania braziliensis and Leishmania infantum were used as control.

The reaction mixture contained buffer $(100 \mu \mathrm{M}$ Tris- $\mathrm{HCl}, \mathrm{pH} 8.5,500 \mu \mathrm{M} \mathrm{KCl}), 50 \mu \mathrm{M} \mathrm{MgCl}_{2}$, 2.5 units of Taq DNA polymerase, $200 \mu \mathrm{M}$ dNTP mix, 2.5pmols of each primer (Ludwig Biotech ${ }^{\circledR}$ ), and $5 \mu \mathrm{L}$ of test DNA (approximately 100 $\mathrm{ng}$ ) in a final reaction volume of $25 \mu \mathrm{L}$. In each PCR assay, a contamination control containing distilled water in substitution for the DNA was used.

The amplification reactions were performed using a gradient thermocycler (Veriti 96 Well Thermal Cycler, Applied Biosystems ${ }^{\circledR}$ ) with the following thermal conditions: initial denaturation at $95^{\circ} \mathrm{C}$ for 5 minutes, followed by 35 cycles of $95^{\circ} \mathrm{C}$ for 30 seconds, $61^{\circ} \mathrm{C}$ for 30 seconds, and $72^{\circ} \mathrm{C}$ for 1 minute and a final extension at $72^{\circ} \mathrm{C}$ for 10 minutes. The PCR products were separated by electrophoresis on a $2.0 \%$ agarose gel and stained with ethidium bromide at $0.5 \mu \mathrm{g} / \mathrm{mL}$. To estimate the size of the amplified fragments, a 100bp molecular weight marker (Ludwig Biotech ${ }^{\circledR}$ ) was used. The amplified products were visualized with a UV transilluminator (Quantum ${ }^{\circledR}$ ST41000/26M).

Fisher's exact test was used to determine the association between the analysis results as a function of the type of habitat of the procyonids,considering $\mathrm{P}<0.05$ and $95 \%$ of confidence interval. The statistical analyses were performed using the BioEstat $\mathrm{V}^{\circledR}$ software version 5.3.

\section{RESULTS}

T. evansi DNA was detected by PCR in $18.52 \%(10 / 54)$ of blood samples from procyonids (Table 1). The PCR generated a 200 bp-length fragment approximately (Figure 2), agreeing the virtual analysis of the primers which indicated that the product size for $\boldsymbol{T}$. evansi was 205 bp, consistent with the size of the products in our PCR assays. The other five tested trypanosomatids species were negative (Figure 3). 
Table 1 - Frequency of positive samples by PCR for Trypanosoma evansi according to species, number of procyonids, origin site (municipality, Brazilian States) and type of habitat.

\begin{tabular}{|c|c|c|c|c|}
\hline \multirow{2}{*}{ Species (Common name) } & \multirow{2}{*}{ Origin } & \multicolumn{2}{|c|}{-------Type of habitat--------- } & \multirow{2}{*}{ Frequency of positive samples ${ }^{3}$} \\
\hline & & Group $A^{1}$ & Group B ${ }^{2}$ & \\
\hline \multirow{4}{*}{ Nasua nasua (coati) } & Marabá, Pará & 1 & 15 & $37.5 \%(6 / 16)$ \\
\hline & Capitão Poço, Pará & 4 & 0 & $25 \%(1 / 4)$ \\
\hline & Benevides, Pará & 1 & 0 & $100 \%(1 / 1)$ \\
\hline & Macapá, Amapá & 0 & 30 & 0 \\
\hline Procyon cancrivorus (crab-eating raccoon) & Capitão Poço, Pará & 2 & 0 & $100 \%(2 / 2)$ \\
\hline Potos flavus (kinkajou) & Macapá, Amapá & 1 & 0 & 0 \\
\hline Total & & $9^{\mathrm{a}}$ & $45^{\mathrm{b}}$ & $18.52 \%(10 / 54)$ \\
\hline
\end{tabular}

${ }^{1}$ Group A: Captive animals.

${ }^{2}$ Group B: Free-living animals.

${ }^{3}$ Values in percentage (\%) and absolute numbers between parentheses. Different letters in columns indicate statistical association (P<0,05; CI 95\%).

All positive samples were from the state of Pará, where the frequency of infection reached 43.48\% (10/23). DNA from T. evansi was detected in $80 \%(8 / 10)$ of blood samples from $N$. nasua, and $20 \%$ (2/10) from $\boldsymbol{P}$. cancrivorus.

DNA from T. evansi was detected in $20 \%$ $(6 / 30)$ of the females and $9.5 \%(2 / 21)$ of the males coatis. Moreover, DNA from T. evansi was detected in two male crab-eating raccoons. Regarding animal habitat, infection was detected in $44.44 \%$ (4/9) of the animals in group A and $13.33 \%(6 / 45)$ of the animals in group $\mathrm{B}$, and a statistical association was observed between these groups $(\mathrm{P}=0.0499)$.

The analysis of the blood smears did not reveal trypomastigote forms of $\boldsymbol{T}$. evansi. Regarding physical inspection, 9.26\% $(5 / 54)$ of the procyonids exhibited mucosal hypopigmentation, and $7.41 \%(4 / 54)$ of them exhibited alopecic lesions. Moreover, nasal secretions (1/54), cachexia $(1 / 54)$, or an opaque coat $(1 / 54)$ was observed in three $N$.

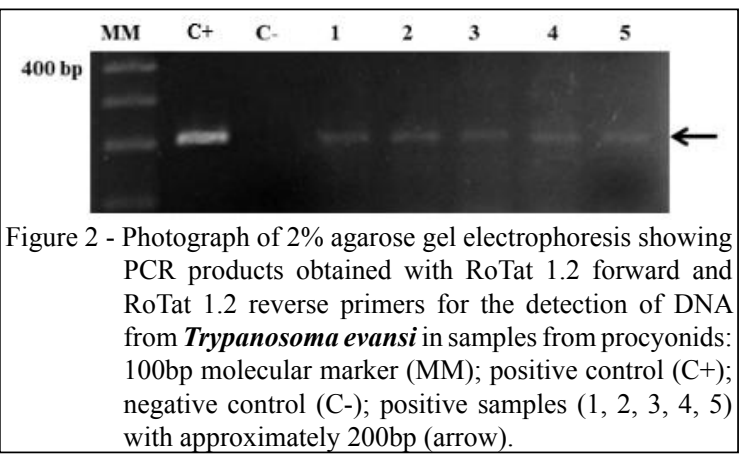

nasua specimens. Among the infected animals, only one animal exhibited alopecia, cachexia, hypopigmented mucous membranes, and an opaque coat.

\section{DISCUSSION}

The present study reports the first molecular detection of T. evansi in procyonids in the Brazilian Amazon region. In Brazil, T. evansi has been diagnosed in horses in the states of Pará (JANSEN, 1941), Mato Grosso do Sul (HERRERA et al., 2004), and Rio Grande do Sul (ZANETTE et al., 2008), where this pathogen is of great importance as the causative agent of "mal das cadeiras" or "surra"; this disease leads to severe economic losses for Brazilian horse breeding due to the treatment costs and the

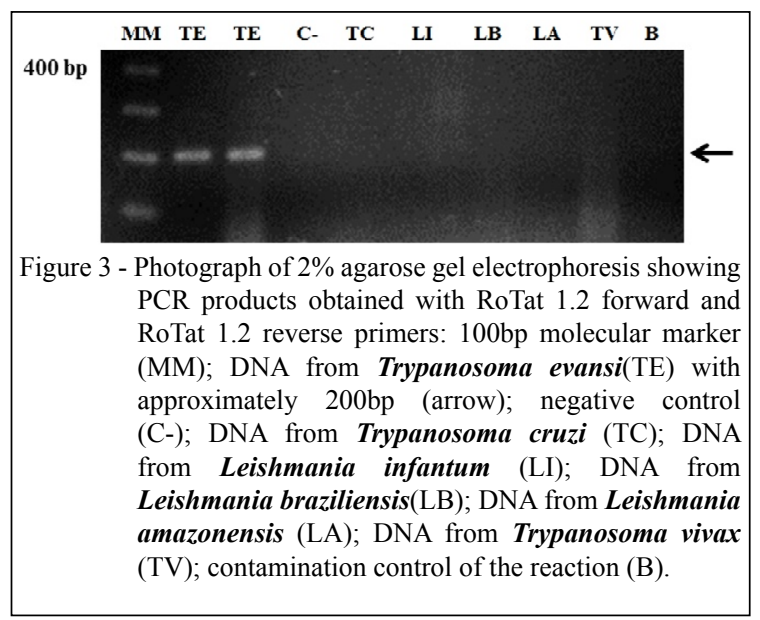


high rates of lethality and mortality (SEIDL et al., 1998). The first disease cases were reported in Marajó Island, Pará State, where the disease was reported to cause high lethality in horses (LACERDA, 1885 apud JANSEN, 1941) and was later considered enzootic in this region (JANSEN, 1941).

Despite the importance of this disease, few epidemiological studies have been performed on the occurrence of T. evansi in the Brazilian Amazon region, especially in wild animals. In the state of Pará, DEANE (1961) conducted a study on hemoflagellates using blood smears of wild animals, including P. cancrivorus and $\boldsymbol{N}$. nasua, and did not detect panosomatids. In the Pantanal region, state of Mato Grosso do Sul, Brazil, NUNES \& OSHIRO (1990) investigated T. evansi infection in different species of wild animals using micro hematocrit centrifugation and inoculation in mice, and the infection of $N$. nasua was detected for the first time, reaching an infection rate of $25 \%$ (4/16). In Eastern Amazon, the infection rate was $18.52 \%(10 / 54)$, as determined by PCR, and infection was detected in both $\boldsymbol{P}$. cancrivorus and $\boldsymbol{N}$. nasua. Of note, this is the first molecular detection of $\boldsymbol{T}$. evansi in $\boldsymbol{P}$ cancrivorus in Brazil, and this procyonidspecies could be considered a new host species.

It is important to note that the PCR based on the RoTat 1.2 forward and RoTat 1.2 reverse primers was able to distinguish $\boldsymbol{T}$. evansi from the other trypanosomatidsspecies. This data was observed too on the virtual analysis by BLAST, and is consistent with the results obtained by CLAES et al. (2004).

The trypomastigote forms of $\boldsymbol{T}$. evansi were not observed in blood smears from the procyonidsexamined, but the infection was detected by PCR, suggesting that these animals can be chronic carriers of this etiological agent. Similar results were obtained by HERRERA et al. (2004), who detected T. evansi infection only by PCR in blood samples of buffalo, bovines, marsupials, small rodents, bats, and armadillos in Pantanal, although these authors observed high parasitemia in capybaras, coatis, horses, and dogs using microhematocrit centrifugation.

Despite allprocyonidspositive samples were from the state of Pará, it can not preclude the possibility of the occurrence of $\boldsymbol{T}$. evansiin Amapá, considering that this state harbors horse herds (IBGE, 2013) and wild mammals (REIS et al., 2010) that can serve as reservoirs, in addition to flies and hematophagous bats that can mechanically transmit the pathogen.

In Pará, the occurrence of infected procyonidswas $43.48 \%(10 / 23)$, and both $\boldsymbol{P}$. cancrivorus and $N$. nasua are susceptibleto T. evansi infection in the study area. Similarly, HERRERA et al. (2011), when describing the epidemiological chain of transmission of T. cruzi and T. evansi in Pantanal, reported that coatis were the main reservoirs for both agents, with the authors detecting animals infection ratesby $\boldsymbol{T}$. evansi of $15.6 \%(18 / 115)$ and $19.1 \%$ $(22 / 115)$ using microhematocrit centrifugation and PCR, respectively. In another study on T. evansi infection (ABDEL-RADY, 2008), PCR exhibited higher sensitivity than blood smears, similar to the results of the present study. Therefore, blood smears are not indicated as the sole diagnostic technique for epidemiological studies on T. evansi.

Although coatis are considered reservoirs for T. evansi, previous studies have reported clinical disease in these animals, with symptoms including depression, weakness, lethargy, and pale mucous membranes (HERRERA et al., 2001). In chronic cases, experimentallyinfected coatis presented with myocarditis, encephalitis, severe anemia, and changes in serum biochemistry (HERRERA et al., 2002). In the present study, only one infected coati kept in captivity exhibited cachexia, alopecia, an opaque coat, and hypopigmentedmucous membranes. However, the nutritional management was found to be inappropriate, which might have contributed to the occurrence of these changes. Moreover, most infected animals efficiently served as reservoirs, exhibiting no clinical signs suggestive of trypanosomiasis caused by $\boldsymbol{T}$. evansi. Changes similar to those observed in infected animals were also observed in some non-infected animals. However, the clinical signs exhibited by the latter were nonspecific and might have been caused by other diseases.

Studies on the natural infection of procyonids by $\boldsymbol{T}$. evansi often involve free-living animals (HERRERA et al. 2004; HERRERA et al. 2011), and little is known about the occurrence of this pathogen in captive animals. In the present study, a significant association was observed between captive animals and the detection of $\boldsymbol{T}$. evansi DNA. This phenomenon may be caused by the stress these animals experience from being maintainedoutside their natural habitat, which can compromise their immune system and predispose them to infection by pathogens. Another important factor involves the physical limitation imposed by captivity, which prevents animal dispersal and makes these animals easy targets for mechanical vectors of T. evansi, such as hematophagousflies.

DNA from $\boldsymbol{T}$. evansi was detected in $\boldsymbol{P}$. cancrivorus and $N$. nasua in Pará State, being this the first such report in $P$. cancrivorus. 


\section{ACKNOWLEDGMENTS}

The authors would like to thanks to the Coordenação de Aperfeiçoamento de Pessoal no Ensino Superior (CAPES), PróReitoria de Pesquisa e Pós-graduação da Universidade Federal do Pará, and Fundação de Amparo e Desenvolvimento da Pesquisa (FADESP) for financial support. We are especially thankful for the institutional support provided by the Fundação Zoobotânica de Marabá, Parque Zoobotânico Adhemar Monteiro, Criatório e Mantenedor Toca da Kuka in Pará Stateand Parque Zoobotânico Arivaldo Barreto, Ceta Ecotel in Amapá State.

\section{REFERENCES}

ABDEL-RADY, A. Epidemiological studies (parasitological, serological and molecular techniques) of Trypanosoma evansi infection in camels (Camelus dromedarius) in Egypt. Veterinary World, v. 1, n. 11, p. 325-328, 2008. Available from: <http:/www.veterinaryworld.org/2008/November/ Epidemiological\%20studies\%20of\%20Trypanosoma\%20 evansi\%20infection\%20in\%20c.pdf>. Accessed: Nov. 20, 2013.

BOEHRINGER, E.G.; PROSEN A.F. Transmission experimental del mal de caderas (Trypanosomiasis equina). Annalesdel Instituto de Medicina Regional, v.5, p.69, 1961.

CLAES, F. et al. Variable Surface Glycoprotein RoTat 1.2 PCR as a specific diagnostic tool for the detection of Trypanosoma evansi infections. Kinetoplastid Biology Diseases, v.3, n. 3, p.1-6, 2004. Available from: <http:// www.kinetoplastids.com/content/3/1/3>. Accessed: Sept. 21, 2013. doi: 10.1186/1475-9292-3-3.

COLPO, C.B. et al. Infecção natural por Trypanosoma evansi em cães. Ciência Rural, v. 35, n. 3, p. 717-719, 2005.Available from: $<$ http://www.scielo.br/pdf/cr/v35n3/a38v35n3.pdf $>$. Accessed: Aug. 12, 2013.

DEANE, L.M. Tripanosomatídeos de mamíferos da região amazônica. I. Alguns flagelados encontrados no sangue de mamíferos silvestres do Estado do Pará. Revista do Instituto de Medicina Tropical, v.3, n.1, p.15-28, 1961.

EISENBERG, J.F.; REDFORD, K.H. Mammals of the Neotropics. The Central Neotropics: Ecuador, Peru, Bolívia, Brazil. Chicago: The University of Chicago, 1999. p. 287-291.

EMMONS, L.H.;FEER, F. Neotropical Rainforest Mammals: a field guide. Chicago: The University of Chicago, 1997. 307p.

HERRERA, H.M. et al. Trypanosoma evansi experimental infection in the South American coati (Nasua nasua): clinical, parasitological and humoral immune response. Veterinary Parasitology, v.102, n.3, p.209-216, 2001. Available from: < http://www.sciencedirect.com/science/ article/pii/S0304401701005325\#>. Accessed: Sept. 12, 2013. doi: $10.1016 / \mathrm{S} 0304-4017(01) 00532-5$.

HERRERA, H.M. et al. Experimental Trypanosoma evansi infection in South American coati (Nasua nasua): hematological, biochemical and histopathological changes. Acta Tropica, v. 81, n. 3, p. 203-210, 2002. Available from: <http://www.sciencedirect.com/science/article/pii/ S0001706X01002042>. Accessed: Sept. 12, 2013. doi: 10.1016/S0001-706X(01)00204-2.
HERRERA, H.M. et al.Enzootiology of Trypanosoma evansi in Pantanal, Brazil. Veterinary Parasitology, v.125, n.3-4, p.263275, 2004. Available from: <http://www.sciencedirect.com/ science/article/pii/S0304401704003462>. Accessed: Sept. 13, 2013. doi: 10.1016/j.vetpar.2004.07.013.

HERRERA, H.M. et al. The coati (Nasuanasua, Carnivora, Procyonidae) as a reservoir host for the main lineages of Trypanosoma cruzi in the Pantanal region, Brazil. Transactions of the Royal Society of Tropical Medicine \& Hygiene, v.102, n.11, p.1133-9, 2008. Available from: <http://trstmh. oxfordjournals.org/content/102/11/1133.long>. Accessed: Sept. 13, 2013. doi: 10.1016/j.trstmh.2008.04.041.

HERRERA, H.M. et al. Food web connections and the transmission cycles of Trypanosoma cruzi and Trypanosoma evansi (Kinetoplastida: Trypanosomatidae) in the Pantanal Region, Brazil. Transactions of the Royal Society of Tropical Medicine \& Hygiene, v.105, n.7, p.380-387, 2011. Available from: <http://trstmh.oxfordjournals.org/ content/105/7/380.long $>$. Accessed: Sept. 13, 2013. doi: 10.1016/j.trstmh.2011.04.008.

IBGE (Instituto Brasileiro de Geografia e Estatística). Amapá - Pecuária. Equinos - efetivo dos rebanhos (cabeças). Publishing in IBGE site, 2013. Available from: <http://cod.ibge.gov.br/27GLB>. Accessed: Feb. 10, 2014.

JANSEN, G. Contribuição ao estudo do mal de cadeiras na Ilha de Marajó. Memórias do Instituto Oswaldo Cruz, v.36, n.3, p.347-371, 1941.

JORGE, R.S.P. et al. Ocorrência de patógenos em carnívoros selvagens brasileiros e suas implicações para a conservação e saúde pública. Oecologia Australis, v. 14, n.3, p.686710, 2010. Available from: <http://xa.yimg.com/kq/ groups/14752436/2009753154/name/jorge+etal2010patogen os+carnivoros.pdf > . Accessed: Dec. 21, 2013. doi: 10.4257/ oeco.2010.1403.06.

LAINSON, R. Espécies neotropicais de Leishmania: uma breve revisão histórica sobre sua descoberta, ecologia e taxonomia. Revista Pan-Amazônica de Saúde, v.1, n.2, p.13-32, 2010. Available from: <http://scielo.iec.pa.gov.br/pdf/rpas/v1n2/pt v1n2a02.pdf $>$. Acessed: Sept. 20, 2013. doi: 10.5123/S217662232010000200002 .

NUNES, V.L.B.;OSHIRO, E.T. Trypanosoma (Trypanozoon) evansi in the coati from the Pantanal region of Mato Grosso do Sul State, Brazil. Transactions of the Royal Society of Tropical Medicine \& Hygiene, v.84, p.692, 1990.

REIS, N.R. et al. Mamíferos do Brasil - Guia de identificação. Rio de Janeiro: Technical Books, 2010.560 p.

SEIDL, A. et al. A financial analysis of treatment strategies for Trypanosoma evansi in the Brazilian Pantanal. Preventive Veterinary Medicine, v.33, p.219-234, 1998. Available from: <http://www.sciencedirect.com/science/ article/pii/S0167587797000494\#>. Accessed: Feb. 02, 2014. doi:10.1016/S0167-5877(97)00049-4.

ZANETTE, R.A.et al. Ocorrência de Trypanosoma evansi em eqüinos no município de Cruz Alta, RS, Brasil. Ciência Rural, v.38, n.5, p.1468-71, 2008. Available from: <http://www.scielo. br/pdf/cr/v38n5/a45v38n5.pdf>. Accessed: Jun. 02, 2013. 